\title{
Education's Role in Democracy: The Power of Pluralism
}

\author{
Barbara J. Thayer-Bacon \\ University of Tennessee \\ Department of Instructional Technology, Health, Cultural Studies \\ bthayer@utk.edu
}

\begin{abstract}
My task in Beyond Liberal Democracy in Schools (2008) was to develop a relational, pluralistic social political theory that moves beyond liberal democracy. I find Dewey is a key source to help us find our way out of liberal democracy's assumptions and show us how to move on. He (1949/1960) offers us the possibilities of moving beyond individualism, with his theory of social transaction and he (1938/1955) shows us how to move beyond rationalism in his arguments for truths as warranted assertions. A transactional description of selves-in-relation-with-others describes us as becoming individuals out of our social settings. At the same time that we are becoming individuals within a social setting, we are continually affecting that social setting. Individuals are not aggregates with separate boundaries that have no relation to one another. In fact, the "self" is fictive, and contingent. Our 'selves' are multifarious and fractured, due to repressive forces imposed upon us by others as well as supportive forces offered to us by others. Others bind us and help us become free at the same time. The democratic theory I develop is a radical democratic theory that represents feminist and multicultural concerns. This theory is radical because of my efforts to present an anti-racist theory that critiques basic foundational-level assumptions embedded within both individualism and collectivism. The theory moves beyond modernism and critical theory as it seeks to address postmodern concerns of power and exclusionary practice without appealing to grand narratives such as Reason, the Scientific Method, or Dialogue. I follow Dewey's social transactional lead and describe our world as one that is pluralistic, relational, and in process as we continually contribute to the on-going constructing of knowing. I argue, in agreement with Dewey (1916/1996), that a democracy is a mode of associated living, not just a view of political democracy, and that it needs to be struggled for on all fronts, with all our social institutions, including: political, economic, educational, scientific, artistic, religious, and familial. This comprehensive view of democracy is consistent with the transactional relational assumption I describe, for it recognizes that social institutions are no more autonomous and separate from each other than individuals are separate from each other. For this essay, I explore education's role in helping us understand how connected we all are to each other, moving us closer to living in a world we may someday call a democracy.
\end{abstract}

\section{Introduction}

My task in Beyond Liberal Democracy in Schools (2008) was to begin to develop a relational, pluralistic social political theory that moves beyond liberal de- 
mocracy. I find Dewey is a key source to help us find our way out of liberal democracy's assumptions and show us how to move on. He (1949/1960) offers us the possibilities of moving beyond individualism, with his theory of social transaction and he (1938/1955) shows us how to move beyond rationalism in his arguments for truths as warranted assertions. A transactional description of selves-in-relation-with-others describes us as becoming individuals out of our social settings. At the same time that we are becoming individuals within a social setting, we are continually affecting that social setting. Individuals are not aggregates with separate boundaries that have no relation to one another. In fact, the 'self" is fictive, and contingent. Our 'selves' are multifarious and fractured, due to repressive forces imposed upon us by others as well as supportive forces offered to us by others. Others bind us and help us become free at the same time.

The democratic theory I am developing is a radical democratic theory that represents feminist and multicultural concerns. This theory is radical because of my efforts to present an anti-racist theory that critiques basic foundationallevel assumptions embedded within both individualism and collectivism. The theory moves beyond modernism and critical theory as it seeks to address postmodern concerns of power and exclusionary practice without appealing to grand narratives such as Reason, the Scientific Method, or Dialogue. I follow Dewey's social transactional lead and describe our world as one that is pluralistic, relational, and in process as we continually contribute to the on-going constructing of knowing.

I argue, in agreement with Dewey (1916/1996), that a democracy is a mode of associated living, not just a view of political democracy, and that it needs to be struggled for on all fronts, with all our social institutions, including: political, economic, educational, scientific, artistic, religious, and familial. This comprehensive view of democracy is consistent with the transactional relational assumption I describe, for it recognizes that social institutions are no more autonomous and separate from each other than individuals are separate from each other.

In this essay I want to look at how John Dewey applied his renascent liberal democratic theory to public schooling, which requires me to begin with a summation of his renascent liberalism before moving on to explore the application of his theory to public education. I will focus on applications to American schools for this text, but I think the argument I make here has implications and applications beyond the borders of the United States, given classical liberal seeds were sewn in Europe, in particular England and France, and their colonies. The resulting values of classical liberalism can be found in school de- 


\section{B.J. THAYER-BACON}

signs and structures throughout the world. Like Dewey, I will argue that a democracy depends on a democratic educational system. I am arguing for the need to move beyond classical liberal democratic theory in our schools and develop a relational, pluralistic democratic educational theory that will create a place where children with diverse cultural roots can thrive. This is what I hope to do, with the help of the many students and teachers from collective cultures whom I have visited over the past several years. I begin this essay's discussion with John Dewey's form of liberalism.

\section{Renascent Liberal Democracy (John Dewey) ${ }^{1}$}

John Dewey's concept of democracy as a mode of associated living, much broader than any particular view of political democracy, as well as his concept of transaction are cornerstone ideas for the relational view of democracy I want to describe. Dewey recognizes we start out as members of communities, in associated living, and that our first community is our family, where we are nurtured, and we experience face-to-face relationships. He (1916/1996) begins his classic work, Democracy and Education with a discussion of social communities, and how individuals develop out of those communities. In many of his writings we can find Dewey discussing infants and their relationships to their mothers as well as their extended families. Contrary to classical liberal philosophers, Dewey does not treat individuals as if they sprout out of the ground without mothers that nurse them and fathers that bathe them. He does not seem to ever lose sight of the fact that we all begin our lives in someone else's loving arms. Dewey developed a sense of self that begins in-relation-withothers, a social self that develops and grows to become more autonomous and rational as we continue to interact with others.

It is not until late in Dewey's career, in his work co-authored with Arthur Bentley (1949/1960), Knowing and the Known, that he introduces the term transactional, but one can find the seeds for this idea in many of his earlier writings, including Democracy and Education. Earlier Dewey used the term "interaction" to describe relationships that affect each other, but later he amended the term to "transaction" because he realized that things can interact with each other without necessarily being affected by the interaction in significant ways, like billiard balls that hit each other on a pool table and bounce off of each other but still maintain their original form. For Dewey, the

${ }^{1}$ This section is derived from Chapter One of my (2003) Beyond Liberal Democracy in Schools. 
result of selves interacting with one another is that both are changed, and, thus, their relationship is more accurately described as a "transaction." Communities help shape the individual into whom s/he becomes, but individual selves, as immature young members of the community, help shape and change the community as well due to their immaturity, which allows them to be flexible, open, adaptive, and growing. In order to explore how Dewey's concept of transaction affected his own view of democracy, I turn to two key later works of his. I begin with Liberalism and Social Action, as I think Dewey offers an excellent analysis of classical liberal political theory and its further developments.

Liberalism and Social Action is from Dewey's Page-Barbour Lectures delivered at the University of Virginia and published in 1935. He begins this series of lectures by laying out the history of liberalism, as he seeks to find what permanent value liberalism contains and how these values can be maintained in the 1930's world of his time. In typical Deweyian style, his method of philosophical argumentation is an historical approach. After pointing to the fact that liberalism can be traced back to ancient Greece and the idea of "free play of intelligence," Dewey begins his historical analysis in earnest with John Locke, in 1688 and his vision that governments exist to protect the rights of individuals. He shows us how Locke's philosophy focuses on the individual, where individualism is opposed to organized social order. For Locke there is a natural opposition between an individual and organized society. Locke was seeking to find a way to get out from under the constraints of society that had developed by his lifetime. He solved this problem by beginning with an assumption that individuals develop on their own, as self-made men, and have the freedom to decide whether or not to join up with others to form a society. The decision to join up with others is always at the expense of the individual's freedom. Locke described democratic governments as offering individuals the service of safeguard and protection, to insure their individual rights are honored and that others do not harm them. However, this is always a precarious governmental service that must be kept in check to make sure that the government does not infringe on individual rights any more than is necessary to protect the society. The relationship between individuals and the government is one of distrust and suspicion; the individual must always be alert to make sure the government is powerful enough to protect individual rights, but not so powerful that it tramples individual rights. Key values of Locke's classical liberalism are that every individual has the right to "the full development of his capacities" and that liberty is "the most precious trait and very seal of individuality" (Dewey, 1935, p. 24). 


\section{B.J. THAYER-BACON}

Dewey's (1935) insightful criticism of early liberalism is that it assumes a conception of individuality "as something ready-made, already possessed, and needing only the removal of certain legal restrictions to come into full play" (p. 39). Dewey tells us the "Achilles heel of early liberalism" is the idea of separate individuals, "each of whom is bent on personal private advantage" (p. 54). Early liberalism did not conceive of individualism "as a moving thing, something that is attained only by continuous growth" (p. 39). Dewey offers us his description of the individual as not starting out in a state of nature prior to entering a social state, but rather as a human infant connected to and cared for by family members. He warns: "liberalism that takes its profession of the importance of individuality with sincerity must be deeply concerned with the structure of human association. For the latter operates to affect negatively and positively, the development of individuals" (p. 41). From Dewey's criticism of early liberalism, we can see that it is clearly the case that Dewey did not begin his own democratic theory with an assumption of atomistic individualism.

Apparently, Locke was not able to see social arrangements as positive forces, but rather as external limitations. According to Dewey (1935), it is not until the second half of the $19^{\text {th }}$ century that the idea arises that the state should be instrumental in securing and extending the liberties of individuals (pp. 5-6). Slowly we see a shift from the idea of using government action only for protection and safeguarding to arguing that we can use governmental action to aid those who are economically disadvantaged, to alleviate their condition. During the $19^{\text {th }}$ century there is a movement in liberal thinking from seeing society as only a hindrance to individuals to beginning to see society as offering assistance and help toward individual development. During the second half of the $19^{\text {th }}$ century in American history we find arguments for the value of public education for children whose parents cannot afford to give their children private education. Horace Mann and others suggest that the government (federal and state) should pay for public education out of public funds raised through individual taxes. Today in political discussions in the USA, Libertarians and conservative Republicans represent the early classical liberal's view of democracy as one where the least government is the best, and Democrats and moderate Republicans represent the new liberals of the $19^{\text {th }}$ century who are committed to using society and the state to help individuals develop to their full capacity.

Dewey (1935) recognizes the important battles that were won by early liberalism in terms of freedom of thought, conscience, expression, and communication. These qualities are what he sees as essential for us to have "freed intel- 
ligence." For Dewey, the enduring values of early liberalism are "liberty; the development of the inherent capacities of individuals made possible through liberty, and the central role of free intelligence in inquiry, discussion and expression" (p. 32). However, Dewey does not regard "intelligence as an individual possession and its exercise as an individual right" as classical liberalism does (p. 65). Intelligence depends on "a social organization that will make possible effective liberty and opportunity for personal growth in mind and spirit for all individuals" (p. 56-57). Again we find evidence that Dewey does not rely on an atomistic view of individualism.

Freed intelligence is a social method that Dewey wants to be identified with the scientific method of investigation. Importantly, because he describes freed intelligence as a social method of inquiry, he recognizes that intelligence is not a ready-made possession; it must be secured. He is very aware that oppressions in terms of slavery, serfdom, and material insecurity are harmful to freed intelligence. He gave the Page-Barbour Lectures during the Great Depression, and he was worried about fascism and communism at the time. Dewey argues for a "renascent liberalism" that recognizes that democracies must establish material security as a prerequisite for individual freedom.

We do find evidence that Dewey's democratic theory relies on an assumption of rationalism in his concept of freed intelligence. Dewey trusted that the scientific method of inquiry would replace brute force as the method of cooperative intelligence. He was greatly influenced by Darwin's Origin of Species, as were other classic pragmatists such as Peirce and James, and he references Darwin's contribution to scientific thinking in many of his writings, including Liberalism and Social Action. In Democracy and Education, Dewey (1916) emphasizes freed intelligence through his discussion of reflective thinking that begins in doubt, where one is stirred to move to action, to generate possible hypotheses and test these out in order to arrive at a conclusion that ends the doubt. Reflective thinking is the scientific method, which by 1935 Dewey describes as "freed intelligence." Predictably, he ends Liberalism and Social Action by pointing to education as the first object of a renascent liberalism, to aid in the producing of habits of mind and character that are necessary for freed intelligence.

Dewey's Freedom and Culture was published in 1939, during the outbreak of World War II when there was great fear as to whether or not democracy would survive. This time Dewey decides to look at democracy in the United States and its development with the help of Jefferson, rather than Locke, since he argues that the conditions in the United States are different from those in Britain. He starts with a cultural focus (to gather up the terms upon which 


\section{B.J. THAYER-BACON}

human beings associate and live together), suggesting we cannot isolate any one factor such as the relations of industry, communication, science, art, or religion. For Dewey, all of these are intrinsic parts of the culture that affects politics, with no single factor being dominant over all others. Dewey criticizes Marxism because it isolates one factor, economics, as being dominant in its discussion of human associations. He tells us that the full conditions for a complete democratic experience do no yet exist.

Using his historical approach again, Dewey (1939) reminds us in Freedom and Culture that America started with an economic focus (rebellion over taxation, restrictions on industry and trade). We find Dewey taking a romantic view of early theory and practice in the United States, presuming harmony between liberty and equality in farming times that changed with the advent of industry. Dewey warns us that we are not going to have democracy until all our institutions are run democratically (church, business, schools, family, law, government, etc.).

In Freedom and Culture, Dewey (1939) connects the future of democracy to a spread of the scientific attitude, as in his "freed intelligence" in Liberalism and Social Action. Here he argues that the scientific attitude is our sole guarantee against widespread propaganda. Dewey recognizes that democracy needs free speech, free press, free assembly, and an education system that encourages inquiry - a scientific attitude. We can secure democracy with all the resources provided by collective intelligence operating in co-operative action (p. 176). Dewey ends Freedom and Culture by returning to Jefferson to underscore that Jefferson was not afraid of change. Jefferson referred to the U.S. government as "an experiment." Dewey encourages us to have the same attitude. He points to the need for face-to-face interaction, political organization in small units, and the need for direct communication in order for democracy to thrive (p. 159). He recommends, "Democracy must begin at home, and its home is the neighborhood community," using a direct quote from an earlier text, The Public and its Problems (1927, p. 213). Again, as in Liberalism and Social Action, he recognizes the need for equalization of economic conditions so free choice and free action can be maintained. Dewey tells us that democratic ends demand democratic methods. His central claim is that "The struggle for democracy has to be maintained on as many fronts as culture has aspects: political, economic, international, educational, scientific and artistic, religious" (p. 173).

What distinguishes the pluralistic, relational democratic theory I present in this essay from Dewey's liberal democracy are his assumptions of rationalism, and universalism that still trail along in his renascent liberalism. We find the 
assumption of universalism in his romantic view of agrarian U.S. society prior to the Industrial Revolution and the influx of immigrants at the turn of the $19^{\text {th }} / 20^{\text {th }}$ centuries. We also find universalism in his romantic view of face-toface interactions in small communities prior to the Industrial Revolution and his recommendation that we need to get back to face-to-face interactions through such methods as town meetings. We discover his assumption of rationalism in his naive view that the scientific method is what will lead us beyond the powerful influence of culture and fears of social determinism and indoctrination. $^{2}$

A pluralistic, relational view of democracy insists that we need to look at America's past from the perspective of African Americans, Native Americans, Mexican Americans (nonvoluntary immigrants and conquered people indigenous to this land), and women and children (viewed as property of males). The wealth of the United States was built on the free, slave, and indentured labor of these people, who were not recognized as citizens until the $20^{\text {th }}$ and $21^{\text {st }}$ centuries (children still are viewed as the property of their parents). The radical view of democracy presented in this essay insists that we consider power issues involved in face-to-face interactions in small communities and the kinds of homogenizing and silencing effects these communities have on diverse opinions and perspectives. The voices of people from the dominant culture who acquired fluency in the dominant language and practiced oral skills and styles of relating valued by the dominant culture were the ones heard in the town meetings that Dewey wanted to go back to, and Benjamin Barber (1984) wants today. People living in the communities who were not considered citizens were not allowed to attend the meetings, or if they were allowed to attend they were seated in the balconies or the back and were not allowed to speak.

The view I offer in this essay also recognizes the limitations of the scientific method and its biases and prejudices that are disguised as neutral and universal, relying on rationality and the valuing of reason. Science has been used to argue racist and sexist biological deterministic views of inferiority for nonAnglos and women. Due to feminist theory and critical theory, we now can recognize that even science is embedded within paradigms that shift over time, and that what we take to be neutral criteria, standards, and principles are negotiated and influenced by the scientists doing the investigating (Deloria 1995,

\footnotetext{
${ }^{2}$ I don't wish to deny the Dewey was active in fighting social justice issues of his time. My criticism is with the lack of attention to racism and sexism in Dewey's democratic theory, not his way of life. I am not the only one criticizing him on these issues. Please see Frank Margonis' (2004) and Charlene Haddock Seigfried's (1996) contributions to this topic.
} 


\section{B.J. THAYER-BACON}

Harding 1991, Keller 1985). With the introduction of minorities and women's views, we have exposed the limits of reason and we now can recognize other valuable tools we use to help us in our inquirying, including intuition, emotions, and imagination (Thayer-Bacon, 2000).

By now we should have a solid understanding of classical liberalism's foundational beliefs as well as problems these beliefs present for democratic theories. By considering Dewey's renascent liberalism in contrast to classical liberalism, we have uncovered his powerful criticisms against classical liberalism. We also learn the limits of Dewey's ability to move beyond his own embeddedness within a liberal culture and discover the biases that affected his criticisms and recommended solutions. I move on to discuss Dewey's democratic theory in terms of education.

\section{John Dewey and the Chicago Lab School}

When John Dewey moved from the University of Michigan to the University of Chicago, he began a lab school that still exists today. The school opened in 1896 and was called the University Elementary School. In 1902 its name was changed to the Chicago Lab School. When it began there were 15 students enrolled, including Dewey's own children, and by 1990 it enrolled 1400 students. The School and Society and The Child and the Curriculum are two series of lectures Dewey gave to the public in Chicago about the Chicago Lab School during its beginning, developing years. He added to the lectures in 1915 for later publications, after he had moved to Teachers College, Columbia University in New York City. I'd like to focus on The School and Society for our discussion, in particular, the first three chapters. Then I will turn to Democracy and Education, which Dewey wrote in 1916, after moving to New York City.

Dewey $(1900,1990)$ starts his lecture, The School and Society, by urging the people listening to take the broader, social view. "Here individualism and socialism are at one. Only by being true to the full growth of all the individuals who make it up, can society by any chance be true to itself" (p. 7). Dewey moves to define society: "A society is a number of people held together because they are working along common lines, in a common spirit, and with reference to common aims. The common needs and aims demand a growing interchange of thought and growing unity of sympathetic feeling" (p.14). He points to changes in society at large, in particular industrialization, which have eliminated household and neighborhood occupations. " $(O)$ ur social life has undergone a thorough and radical change. If our education is to have any mean- 
ing for life, it must pass through an equally complete transformation" (p. 28). Already we can see that Dewey is striving to bring the individual and others together and show how they interact with each other, and are dependent on each other. We can find the seeds of what I am growing into a theory of transactional relationships. We also can see how Dewey's philosophy of education could stimulate and support communitarian ideas such as Barber's (1984), as he places a strong emphasis on commonality.

Dewey $(1900,1990)$ tells us that the aim of the Chicago Lab School is to connect school to home and the neighborhood, and to connect history, science, and art. They want a school that is like an ideal home, with a family-type atmosphere. In Chapter One of The School and Society, we come across one of Dewey"s often cited lines, "What the best and wisest parent wants for his own child, that must the community want for all of its children" (p. 7). Dewey argues that the school needs to take on the job of teaching tasks/skills that were formerly taught at home: work in metal and wood, weaving, sewing, and cooking for example. In his school these occupations are made centers of school life, "active centers of scientific insight into natural materials and processes", which he illustrates with sewing and weaving (p. 19). He also tells us that the school seeks to encourage a spirit of free communication, an interchange of ideas (p. 16). He describes the school as offering "embryonic communities." Dewey suggests: "When the school introduces and trains each child of society into membership within such a little community, saturating him with the spirit of service, and providing him with the instruments of effective selfdirection, we shall have the deepest and best guaranty of a larger society which is worthy, lovely, and harmonious" (p. 29). Dewey offers a significant contribution to democratic theory by connecting the home and school to society, and arguing that it is important to look at what we do in our homes and in our schools, for that is where we teach our children how to be members of democratic societies. Notice how his focus is on harmony, suggesting an emphasis more on commonality than individuality and difference, as well as an emphasis on harmony over conflict and disagreement. Also, notice how his emphasis is on reason, with his desire for free communication and an exchange of ideas. Still, his examples are practical and holistic: cooking, sewing, and weaving.

In Chapter Two, Dewey $(1900,1990)$ shows how public schools are designed for listening and for mass education with their uniform curriculum and methods. He looks at the ideal home, and then enlarges that ideal to come up with his description of an ideal school. He reminds us that the aim of the school is to further the growth of the child. He discusses various "instincts" that chil- 


\section{B.J. THAYER-BACON}

dren have: social, language (interest in conversation), inquiry (interest in finding out things), construction (interest in making things), and artistic expression. Then he gives examples that exist in his school where we can see them bringing together these "instincts." Dewey seeks to create a school where the students learn scientific directed inquiry. "When nature and society can live in the schoolroom, when the forms and tools of learning are subordinated to the substance of experience, then shall there be an opportunity for this identification, and culture shall be the democratic password" (p. 62). We can find in this chapter the seeds of Dewey's (1916) later emphasis on scientific inquiry, or what he later called "reflective thinking." We can also find his underscoring of the importance of learning through experience, as well as his valuing of the arts for learning. What's interesting to note is that his discussion of "instincts" again emphasizes children's universality, not their cultural differences. His reference to the "ideal home" also emphasizes universality and commonality, not cultural differences. He does not discuss questions concerning what counts as an "ideal home." Even Dewey's reference to "culture as the democratic password," is not to draw our attention to cultural differences but instead to underscore the role cultures - meaning the arts and language - have in bringing us together. We can see that Dewey evades questions of power and assumes a neutral, objective position that denies his own location within a particular culture, and the fallibility and subjectivity of his own judgments concerning what counts as an ideal home or a cultural experience. These are criticisms that Laclau and Mouffe (1985) and Young (2000) would bring to bare on his work.

Chapter Three looks at school as an institution in relation to society and to its members - the children. Its focus is on waste in education. Here Dewey $(1900,1990)$ deals with the question of organization. Dewey traces the history of the development of schools, and shows the lack of unity and coherence in schools. He tells us and shows us through a chart that the Chicago Lab School connects to home, business, nature, and the university. He has another chart to show how the school is structured within, with a library in the center of the building, and a shop, textile industries, kitchen, and a dining room around the center. With this school structure, Dewey seeks to connect theory to practice. He shows us with another chart, how within the school there could be a second story to the building with a museum in the center, with art, music, physical and chemical labs, and biological labs around the center. Dewey's hope is for a synthesis of art, science, and industry. He advises his listeners, and readers: "Relate the school to life, and all studies are of necessity correlated" (p. 91). He tells us he is not looking for others to imitate what he's doing; he just wants to show that this type of school is feasible. Here again we find Dewey's 
very important contribution to democratic theory, through his connecting of schools to home, business, nature, and the university. He makes it clear that there is a link between democracy and education and that how we structure our schools as well as what we do within those schools in terms of what we teach and how we teach matters in trying to establish and sustain a democratic society. His examples of school design are holistic and relevant still today. He brings together in a very interdisciplinary way subject areas that schools today still tend to keep separate and artificially divided. He values the arts, including music, fine art, and vocational art, as much as he values science and reading. Dewey certainly succeeded in showing the Chicago Lab School was feasible. It has stood as a model for how schools can be for a century.

When we turn to Dewey's $(1916,1996)$ classic Democracy and Education we find that Dewey does not overcome his assumption of neutral universality and his neglect of plurality and diversity, although he does address universality somewhat in some places such as in his discussion of educational aims. We also find that he still evades questions of power. However, he does further develop his idea of transactional relationships between individuals and others (without using that term). We also find that he maintains and further develops his holism, as well as his emphasis on scientific inquiry through his discussion of reflective thinking. It is not my intention here to discuss Democracy in Education in detail, there are too many others who have already accomplished that task very well, for me to duplicate their efforts. ${ }^{3}$ What I want to do is sketch how his thoughts further develop after leaving the Chicago Lab School behind, especially in regards to a transactional view of individuals-in-relation-to-others.

Dewey (1916, 1996) begins Democracy and Education in a very promising way, in terms of the hope of moving beyond individualism, for he begins by emphasizing that education is a social need. All living things have the need to maintain themselves through renewal, thus establishing a continuity of life, and education is how people renew themselves and provide social continuity. Dewey starts by underscoring that human beings are social beings that live in communities by virtue of the things they have in common. They establish what they have in common through communication. He emphasizes that in order for people to communicate with others about their experiences they have to be able to get outside of their own point of view and formulate their experiences so that they connect to others' lives somehow, so that appreciation of their meaning can be established. To be a community, people have to share purposes and have a communication of common interests. Education is the sharing of experience that gives experience meaning, and it can occur for- 


\section{B.J. THAYER-BACON}

mally, through direct tuition, as well as informally and incidentally through the sharing of actual pursuits.

From this very promising beginning that emphasizes how connected individuals are to others, Dewey $(1916,1996)$ moves on to discuss how to keep a balance between formal and informal education, and most important to him, how to maintain conditions that promote active, growth stimulating forms of formal education. He discusses how education is not just the sharing of experiences but the "continuous reconstruction of experience" (p. 80) "which adds to the meaning of experience, and which increases ability to direct the course of subsequent experience" (p. 76). For Dewey, this reconstructing of experiences may be social as well as personal.

There are many places throughout Democracy and Education where we can find Dewey $(1916,1996)$ continuing to discuss in various ways how connected individuals are to others. In Chapter 3, "Education as direction," he shows that if we begin with an assumption that people are by nature self-centered and selfish (classical liberalism and utilitarianism make this assumption), we must assume that people are antisocial and need to be controlled. Dewey argues that there are no grounds to assume egoism. We are interested in ourselves, yes, but we are also interested in others, on the whole. This is why we have community, according to Dewey. Chapter 4, "Education as growth," is a famous appeal to respect immaturity. Dewey makes the case that immaturity should be viewed in a positive way as meaning "capacity" and "potentiality." Immature people, such as children, are open to learning, due to their plasticity. We can describe them in terms of what they lack, but we can also describe children in terms of what they are capable of, in terms of their possibilities. The same is true with children's dependence, Dewey shows, for we can see them as needing others to take care of them and not being able to care for themselves, but we can also notice how skillful children are at getting others' attention and letting them know what they need. Children are very good at getting others to provide for them. Again we find that Dewey describes children in relation to their childcare providers, in connection with each other and affecting each other, requiring others attention and being especially adept at being flexible and open to learning, as well as skillful at getting others to attend to their needs. Dewey's descriptions of selves are in relation to others.

When we come to Chapter 7, "The democratic conception in education", we find Dewey's famous definition of democratic societies, as well as how democracy connects to education. By now he has established that education is "a social function, securing direction and development in the immature through their participation in the life of the group to which they belong" (p. 81), but 
this says nothing about the quality of the social process. Because education is so tied to the life of the group, the people we associate with, Dewey turns to considering how to measure the worth of various forms of social life. For Dewey there are two ways of measuring the worth of a form of social life: 1) the extent in which the interests of a group are shared by all its members, and 2) the fullness and freedom with which it interacts with other groups (p. 99). These two criteria are what he uses to make the case that the best form of associated living is a democracy. The need is for a society where people have the opportunity for free intercourse and communication of experience. A democratic society is "(a) society which makes provision for participation in its good of all its members on equal terms and which secures flexible readjustment of its institutions through interaction of the different forms of associated life [... ]" (p. 99). Dewey ends this chapter by claiming that democratic societies must have an educational system "which gives individuals a personal interest in social relationships and control, and the habits of mind which secure social changes without introducing disorder" (p. 99).

Much of Dewey's (1916, 1996) Democracy and Education is an effort to heal splits that have developed in philosophy, such as between thinking and doing, theory and practice, the mind and the body, work and leisure, man and nature, and the individual and the world. I end my discussion of Democracy and Education by pointing to one more example of Dewey's efforts to move us beyond individualism, in a transactional direction. In Chapter 22, "The individual and the world," Dewey seeks to heal the split that has developed in modern times between individuals (the mind) and the world (others). He describes for us the historical development of this fairly modern idea that individuals have their own minds, in an effort to show us that philosophers misunderstood practical individualism, the struggle for greater freedom of thought in action, and mistakenly translated it into philosophical subjectivism (p. 293). "Men were not actually engaged in the absurdity of striving to be free from connection with nature and one another. They were striving for greater freedom in nature and society. [...] They wanted not isolation from the world, but a more intimate connection with it" (p. 294). Again he reasserts: "As matter of fact every individual has grown up, and always must grow up, in a social medium. His responses grow intelligent, or gain meaning, simply because he lives and acts in a medium of accepted meanings and values. Through social intercourse, through sharing in the activities embodying beliefs, he gradually acquires a mind of his own. [...] The self achieves mind [...] the self is not a separate mind building up knowledge anew on its own account." (p. 295, author's emphasis) 


\section{B.J. THAYER-BACON}

If we assume an egoistic consciousness we end up with solipsism, action that cannot have regard for others. These are powerful, important thoughts Dewey had about individuals in relation to others that are still in need of discussion today. He is indeed guilty of charges that Young (2000) might make against him, that he emphasizes harmony and commonality at the expense of valuing diversity, or that Fraser (1997) might make against him in terms of bracketing questions of political economy and material needs. Dewey is indeed vulnerable to charges that Laclau and Mouffe (1985) might make against him, that he slides into a tone of assumed neutral universality and misses confronting issues of power.

We have discovered that Dewey does plant very important seeds that open up possibilities for creating democratic spaces that do value diversity and do make room for more holistic descriptions of learning. Most important for my task here, we have learned that Dewey continues to describe selves-in-relationto-others in his philosophy of education, in contrast to the atomistic individualism of classical liberal democratic theory and utilitarianism embraced during his lifetime. Dewey emphasized for us that the home and school are connected to each other, and both are connected to our larger society. What he describes is the transactional relationship between home, school, and society, that they all affect each other and are changed as a result of their interactions with each other. A society that seeks to be a democracy-always-in-the-making is dependent on its children learning how to be the kinds of citizens a democracy requires. Our homes and our schools are two of our social institutions that offer children the chances to learn these habits of heart and mind. Dewey reminds us that children have to learn to take an interest in each other's well-being and they need to have many opportunities to freely interact and relate to each other, as they learn how to get along and work together. He warns us of the need for children to lean how to secure social changes without introducing social disorder, so that democracies will not slide into chaos. He also stresses the importance of connecting theory to practice, a synthesis of art, science, and industry, through the design of school curriculums. We will take his recommendations to heart below. Let's consider now how Dewey's ideas concerning democracy and education can further grow in soil that is informed by feminist, multicultural, and postmodern concerns of power and exclusionary practice. 


\section{Education's Role in Democracy ${ }^{3}$}

Classical liberalism worked hard to try to separate some social institutions so that governments would not be able to claim authority over peoples' religious expressions (what church, if any, they were allowed to attend), or dictate to parents how to raise their children or even if parents should be the ones to raise their children (in slave cultures, children are taken away from their parents, as happened in the Americas' dark past with African, Native, and Mexican parents and their children). Liberal democracy fought to keep governments from overtaxing their citizens, so that people could reap the rewards of their own hard work and pass those rewards on to their children, rather than to the state.

Liberal democracy offered a way to critique social institutions by making the case that are social institutions are not divine but humanly constructed, and therefore, open to critique and reconstruction. However, no matter how hard liberal democracy works to separate social institutions from each other and draw secure boundaries around them, it never seems to work. There is a reason for this - the boundaries are socially constructed, artificial, and impossible to maintain. They are leaky and porous, flowing into each other continuously so that all we are able to maintain is the illusion of separation. Our views concerning the role of the government inform our views concerning the role of parents, our spiritual leaders, and our teachers. In a society such as the United States, where governments are feared for their power, and a system of checks and balances is set up to limit their power, it is not surprising to find that parents also fear teachers having too much power and influence over their children and a system of checks and balances is put in place in schools as well. Principals with strong authority direct the daily running of the schools and observe and evaluate their teachers, superintendents evaluate the principals, and school boards evaluate the superintendents, while the states (and now the nation) design benchmark examinations for students in order to make sure everyone is doing their jobs and is held accountable.

The effort to separate social institutions and protect them from the power of the government (or the church) is based on a view of government as one that intrudes upon us. Again, it is a view of associations with others as hindrances and something we need protection from as individuals. As we learned above with Dewey (1935), classical liberalism evolved during the 1800's to a point where the state began to be recognized as being important for more than just

${ }^{3}$ This section and the conclusion is derived from Chapter Seven of my (2003) Beyond Liberal Democracy in Schools. 


\section{B.J. THAYER-BACON}

protection and safeguarding; it began to be viewed as necessary to secure and extend individual liberties by aiding those who are economically disadvantaged. Democratic governments began to be viewed not only as necessary hindrances that must be kept in check because they continually threaten to become too powerful and infringe upon our individual freedoms, but also as having an important role to play in assisting citizens to reach their full potentials as individuals. Instead of relying solely on a myth of merit - that if I just work hard enough, I will be able to succeed and have the opportunity to reap the benefits of my hard work - people began to acknowledge that not everyone starts life under the same fair conditions. Some people get assistance to help them begin to establish the fruits of their labor, and some people do not. Some families have material wealth and can hire private tutors for their children or pay for the best medical services, while others cannot.

The role of government in a democracy shifted in the $19^{\text {th }}$ century from one that supplies protection from harm, to one that is also a provider. The role of protector relies on a logic of fear and distrust of others. The role of provider relies on a logic of paternity, viewing the government as responsible for the care of citizens who are not able to care for themselves. This view of the government's role is paternalistic in that it assumes a benefactor role from a position of strength, assurance, and wealth. It is a position of power that allows the government to judge what is lacking or deficit in people's lives and determine how to rectify that deficit. It positions the citizens it assists as lacking, deficit, and needy. A paternalistic government does not treat its citizens with dignity and respect or as equals. Rather, it treats them from a position of moral strength and judges them to be inferior and in need of help. A government in the role of provider is a government in a position of arrogance, which is certainly how "welfare mothers" view the social workers who check on them to determine if they qualify for federal assistance, and is certainly how many nations that receive assistance from America view the United States.

If we look to social democratic countries such as Sweden, Finland, Norway, and Canada as examples, we find countries that, without assuming the paternalistic role of provider, have been able to create governments that ensure the equitable distribution of wealth to those who are lacking in material goods, thus breaking down extreme differences between the wealthy and the poor. Time and again, Americans opt for what they think benefits themselves and offers them the most individual freedom and choices, at the expense of others whom they justify deserve less because they must be lazy, incompetent, uninformed, lacking in ability, less deserving, or just plain unlucky. The values of individual freedom, choice, and competition trump the values of fraternity, 
equality, cooperation, and a sharing of resources regularly in American political decisions. To much of the rest of the world, while we may be envied for our perceived wealth and opportunities (which many immigrants find are not available to all, but to just a select few), we are distrusted and even despised for what they perceive as our selfish greed as we use up more than our fair share of resources and refuse to share with others or clean up after ourselves, and for our unfathomable arrogance in believing we deserve what we have (the myth of merit), even though our wealth has come through the exploitation of others less powerful (the Indians, Mexicans and Africans we enslaved, immigrants from other countries such as Ireland and China, and now our exportation of our companies to countries where they can hire cheaper labor, such as Mexico, India, Pakistan, and Sri Lanka).

I (2008) argue in Beyond Liberal Democracy in Schools that governments in democracies-always-in-the-making should serve roles very similar to those that teachers serve in classrooms: roles as facilitator and resource, guide and mentor, advocate and supporter, translator and referee. Our government, church and business leaders, our teachers, community members, and parents all share a responsibility to help our children develop into adults who will be able to participate in a democratic society always-in-the-making. We need the adults in our children's lives to create and nurture fertile ground for the children to grow by making sure their basic needs are taken care of (such as a place to sleep, food to eat, clothing and shelter, protection from harm, loving arms to hold them). This means we need our governments to address universal issues such as health care, job opportunities, retirement benefits, and access to quality schooling to make sure the resources we have are shared so that no child goes without their basic needs being met. When laws such as "No Child Left Behind" are passed in America that do not address social issues that affect children's basic needs then they are empty promises. It is easier for legislatures to blame teachers for lowered expectations and order children to take more tests than it is to actually try to address difficult social issues such as lack of health care, unemployment rates, and the rising cost of living that put so much stress on families that they reach their breaking point.

We need our governments to help us find ways to work together and solve our problems, not to solve them for us but to serve as facilitators, giving us forums for discussing and airing our issues and concerns and avenues for sharing our views with others beyond the reach of any particular forum. We need our governments to serve as a resource and help us find information we need to solve our problems, including making available experts in human resources who are trained to deal with particular issues and concerns. We need our gov- 


\section{B.J. THAYER-BACON}

ernments to serve as mentor and guide to help people develop their knowledge so they can become experts in problems that need solutions. We need our governments to advocate for us when our rights are violated and support us in our efforts to grow and develop. We need our governments to serve as translators to help us understand one another and find ways to work together, to help us overcome our flaws and limitations, appreciate and value our differences, and recover from our mistakes and misunderstandings.

We need our governments to help us gather together our resources and serve as the place of deposit and distribution, like storage closets that hold the supplies for us that we will need access to for working on problems and issues, including the cleaning supplies we need to clean up after ourselves. We need them to keep an inventory of our resources and inform us when there is a need to replenish supplies. We need our governments to make sure we all have equal access to the supplies and that we don't use more than our fair share, or forget to put what we use back on the shelf in the closet for others to use. As a referee, we need our governments to make sure we play fairly and follow the rules we agree upon and blow the whistle on us when we don't. If we find we do not like the rules we have created to live by, we need our governments to offer us a forum for discussing and deciding how we want to change the rules.

I agree with Young (2000) that we need to make sure we teach our children to appreciate their differences in our efforts to affirm diversity and plurality. They need to know that they do not have to like one another or agree with one another; that it is okay to disagree. In fact, it is important for them to understand and expect that they will not find anyone who agrees with them all the time. However, in attempting to find ways to work together and share our limited resources, we must teach our children to continually pay attention to others' needs and how their choices and actions might be affecting others. Our children need to know that while they share much in common with others, they also have much that is different, and that this is not only okay but a great good, for it is through those differences that we are able to become more aware of our own limitations and open up possibilities for more solutions to our problems. I agree with Laclau and Mouffe (1985) that it is vital for our children to grow up aware of and able to recognize oppression and exploitation, to understand that domination and inequality are harmful to all of us as we seek to live together in democracies-always-in-the-making, and that they need to learn ways to resist these harms to themselves as well as to others. A transactional view of individuals-in-relation-to-others is what will help us maintain a pluralistic view of democracies and protect us of from fears of so- 
cial determinism, not Mouffe's (1993) individual freedom and personal autonomy or Young's (2000) self-development and self-determination.

What kind of democratic citizens can we hope for when we start with an assumption of transactional relationships, emphasizing how much we are connected to each other and affect one another as well as how much we are disconnected from one another? When we acknowledge how much we have in common with one another, as well as how different and strange we are from one another, then how much can we effect change in the world and how much the world affects who we are and what we do. We have to hope for citizens who:

- are able to make decisions and not act solely on the basis of their own needs, but take the needs of others into account as well;

- value others and treat others with respect and dignity;

- are caring of others and able to attend to others with generosity and feel empathy for others who are different and strange from themselves;

- are patient and generous, able to share with others, wait their turns, and are willing to offer a helping hand;

- are self-reflective and seek to learn from their mistakes;

- seek to continually improve their abilities to communicate and relate to others different from themselves;

- are able to take responsibility for their own limitations and fragilities and apologize and try to correct their mistakes and fix the harm they do;

- are intellectually curious and continually develop their inquiry skills and improve their abilities to research, problem solve, and think constructively;

- are willing to work hard, expect much from themselves, and encourage others to work hard too;

- are persevering and resilient, able to keep trying and not give up easily when they run into problems; and

- are brave and courageous, and are able to take action against wrongs and help to right them.

Within this general description of democratic citizenship, there is tremendous room for diverse expressions of these values. As I consider these qualities from the diverse cultural perspectives of the various teachers $I$ have had the chance to get to know in my project I am confident they would all embrace the importance of these qualities, and probably have more qualities they 


\section{B.J. THAYER-BACON}

would want to add to the list. I am also sure that they would find a variety of ways to express these qualities and would agree that there are more ways of expressing democracies-always-in-the-making than all of us included can imagine.

\section{Conclusion}

We live in times where there are great changes in political philosophy and in societies at large. These are times when key assumptions of liberal democratic theory are being questioned and dismissed. My voice is included in the chorus of criticisms of liberal democracy's assumptions of rationalism, universalism, and individualism. I am offering a relational, pluralistic social political theory that moves us beyond liberal democracy. In this essay I have turned to John Dewey, one of America's classic pragmatists, to help me show the need for change, and to help me in the development of the change I offer.

I have suggested that there is a way out of the either/or logic of classical liberal and collective values by embracing a transactional assumption of selvesin-relation-with-others, which relies on a both/and logic to describe individuals and others as influencing and affecting one another. This transactional assumption also applies to the social institutions we have constructed in our various cultures: our families, churches, economies, governments, and schools, for example. I have made the case that these social institutions influence and affect one another as well; they are connected and part of one whole. Our social institutions are individuals-in-relation-to-others at a macro level; they represent the same transactional relationship on a larger scale. Just as the borders between individual selves are artificially drawn, so, too, are the borders we erect between our social institutions as we try to make sense of our world and give it meaning. These borders cannot hold up to close scrutiny, for their edges are fuzzy, like dotted lines that appear solid from a distance but disappear if we look closely. I have argued that if we try to address one social institution, such as education, while ignoring others, such as economies and families, we are doomed to failure, for it is only through addressing the transactional relationship between them all that we will have a chance of addressing problems within particular social institutions and making changes.

Such a complex, interrelated description of our world may make it seem like there is no chance of ever effecting change in our social institutions. Where do we begin? What steps do we take that will start the process of change? And what hope can we ever have of seeing the changes take effect? Though the task 
may seem overwhelming, it is nevertheless possible to improve conditions in our education systems, but we must pause and consider the results of our actions before we act. Our actions are interconnected and our world is continually in a state of flux as actions cause reactions and affect us. We must lose our arrogance and unquestioned confidence that we know what to do to "fix things", and gain more respect for the complexity of situations. We must move more cautiously and humbly, recognizing that those at the local level who are must directly affected may understand the conditions necessary for change better than we, as outsiders, do, but we must also recognize that our outsider perspectives might be useful to insiders by contributing to the expansion of their thoughts about situations.

While it may seem impossible to effect changes in our social institutions and improve social conditions with the transactional description of our world that I offer, it is surely impossible not to effect changes in this living, breathing world. If we start with a transactional view of our world, we realize that we are continually in a state of flux. Schools that seem never to change are, in fact, always in a state of movement and change. From a transactional perspective, it is not a matter of where do we begin and how do we get started, but one of becoming aware that we are always, already in process and we cannot stop. Instead, we need to worry about how we are effecting change and how our actions are affecting others.

I have argued that classical liberalism has spread its values of individual freedom, choice, and autonomy far and wide, due to colonization of other parts of the world by Euro-western nations, such as England and France, and, more recently, the United States, which embrace those values. These values have poisoned indigenous cultures and are having the same effect on other collective cultures today. I offer a transactional view of individuals-in-relationto-others as a powerful antidote to classical liberalism. I do not think classical liberalism will ever lead us to democracies; the exclusionary either/or logic of liberalism in fact contradicts the very idea of 'democracy,' which is inclusive and welcoming of others who are not like us. It is my great hope that the transactional view I offer here gives us ways to imagine that we can work toward a democracy that is welcoming of all our children.

\section{Bibliography}

Barber, B. (1984). Strong Democracy. Berkeley: University of California Press. Deloria, Jr., V. (1995). Red Earth, White Lies. New York: Scribner's Sonds. 


\section{B.J. THAYER-BACON}

Dewey, J. (1990). The School and Society [1900], The Child and the Curriculum [1902]. Chicago: The University of Chicago Press.

Dewey, J. (1916, 1944, 1966, 1996). Democracy and Education. New York, The Free Press.

Dewey, J. (1927). The Public and its Problems. New York: Henry Holt and Company.

Dewey, J. (1935). Liberalism and Social Action. New York: G. P. Putnam's Sons.

Dewey, J. (1939). Freedom and Culture. New York: G. P. Putnam's Sons.

Dewey, J. (1938, 1955). Logic: The Theory of Inquiry. New York: Henry Holt and Company.

Dewey, J. and Bentley, A. F. (1949, 1960). Knowing and the Known. Boston: Beason Press.

Fraser, N. (1997). Justice Interruptus. New York: Routledge.

Garrison, J. (1997). Dewey and Eros. New York: Teachers College Press.

Harding, S. (1991). Whose science? Whose knowledge? Thinking from Women's Lives. Ithaca: Cornell University Press.

Keller, E. F. (1985). Reflections on Gender and Science. New Haven: Yale University Press.

Laclau, E. and Mouffe, C. (1985). Hegemony and Socialist Strategy, W. Moore and P. Cammack (Trans.). London: The Thetford Press Ltd.

Margonis, F. (2004). The path of social amnesia and Dewey's democratic commitments. In K. Alston (Ed.), Philosophy of Education Society 2003 (pp. 296-304). Urbana: University of Illinois Press.

Mouffe, C. (1993). The Return of the Political. London: Verso.

Noddings, N. (1995/2007). Philosophy of Education ( $2^{\text {nd }}$ Edition). Cambridge: Westview Press.

Seigfried, C. H. (1996). Pragmatism and Feminism. Chicago: University of Chicago Press.

Thayer-Bacon, B. (2000). Transforming Critical Thinking. New York: Teachers College Press.

Thayer-Bacon, B. (2008). Beyond Liberal Democracy in Schools. New York: Teachers College Press.

Young, I. M. (2000). Inclusion and Democracy. Oxford: Oxford University Press. 